International Journal of Environmental Research and

Public Health

ISSN 1660-4601

www.mdpi.com/journal/ijerph

Review

\title{
Healthy Food Procurement Policies and Their Impact
}

Mark L. Niebylski ${ }^{1}$, Tammy Lu ${ }^{1}$, Norm R. C. Campbell ${ }^{1}{ }^{*}$, Joanne Arcand ${ }^{2}$, Alyssa Schermel ${ }^{2}$, Diane Hua $^{3}$, Karen E. Yeates ${ }^{4}$, Sheldon W. Tobe ${ }^{3}$, Patrick A. Twohig ${ }^{5}$, Mary R. L'Abbé ${ }^{2}$ and Peter P. Liu ${ }^{5}$

1 Libin Cardiovascular Institute of Alberta, University of Calgary, 3280 Hospital Drive NW, Calgary, AB T2N 4Z6, Canada; E-Mails: mniebylski@yahoo.com (M.L.N.); tamlu@ucalgary.ca (T.L.) Department of Nutritional Sciences, Faculty of Medicine, University of Toronto, 150 College St., Toronto, ON M5S3E2, Canada; E-Mails: joanne.arcand@utoronto.ca (J.A.); a.schermel@gmail.com (A.S.); mary.labbe@utoronto.ca (M.R.L'A.)

3 Sunnybrook Health Sciences Centre, Sunnybrook Research Institute, University of Toronto Bayview Ave. E239, Toronto, ON M4N 3M5, Canada; E-Mails: Diane.Hua@sunnybrook.ca (D.H.); sheldon.tobe@sunnybrook.ca (S.W.T.)

4 Department of Medicine, Queen's University, 2059 Etherington Hall, Kingston, ON K7L 3N6, Canada; E-Mail: yeatesk@queensu.ca

5 Toronto General Hospital, University of Toronto, 200 Elizabeth St., Toronto, ON M5G 2C4, Canada; E-Mails: ptwohig@uhnresearch.ca (P.A.T.); peter.liu@ utoronto.ca (P.P.L.)

* Author to whom correspondence should be addressed; E-Mail: ncampbel@ucalgary.ca; Tel.: +1-403-210-7961; Fax: +1-403-210-9837.

Received: 16 December 2013; in revised form: 19 February 2014 / Accepted: 19 February 2014 / Published: 3 March 2014

Abstract: Unhealthy eating is the leading risk for death and disability globally. As a result, the World Health Organization (WHO) has called for population health interventions. One of the proposed interventions is to ensure healthy foods are available by implementing healthy food procurement policies. The objective of this systematic review was to evaluate the evidence base assessing the impact of such policies. A comprehensive review was conducted by searching PubMed and Medline for policies that had been implemented and evaluated the impact of food purchases, food consumption, and behaviors towards healthy foods. Thirty-four studies were identified and found to be effective at increasing the availability and purchases of healthy food and decreasing purchases of unhealthy food. Most policies also had other components such as education, price reductions, 
and health interventions. The multiple gaps in research identified by this review suggest that additional research and ongoing evaluation of food procurement programs is required. Implementation of healthy food procurement policies in schools, worksites, hospitals, care homes, correctional facilities, government institutions, and remote communities increase markers of healthy eating. Prior or simultaneous implementation of ancillary education about healthy eating, and rationale for the policy may be critical success factors and additional research is needed.

Keywords: public policy; health promotion; health; food; non-communicable disease; sodium; sugar; saturated fat; trans fatty acids

\section{Introduction}

A growing proportion of the global population has diet-related non-communicable health risks and diseases (NCDs), such as obesity, hypertension, dyslipidemia, diabetes, heart disease, stroke, or cancer [1-17]. These largely result from unhealthy lifestyle choices in unhealthy living environments, and cost billions of dollars every year, threatening economies and the sustainability of health care systems around the world $[1,18]$. NCDs account for over $63 \%$ of deaths and it is estimated that $40 \%$ of these NCD-related deaths are attributed to diet [19-23]. The main dietary factors causing disease are excess intakes of free sugar, saturated fats and trans-fatty acids, and sodium, much of which is added during food processing and a lack of fruits and vegetables [1-7,24]. To reduce the burden of NCDs, there is a subsequent call for population health interventions to improve the quality of dietary intakes [18].

There are several potential policy interventions that can support healthy eating. Healthy food procurement policies require that the food purchased, provided, or made available is healthy (or at least healthier) and the policies are often directed at people who have a large proportion of their daily intake from a central organization (e.g., schools) [25-27]. A definition of healthy food procurement that has been used in a review of policies is "a process which encompasses not just how public bodies procure food, but also how they determine what food they want to buy and from whom; receive and store food; prepare and serve food; dispose of waste food; and monitor their costs" [26]. Broad implementation of healthy food procurement policies have the potential to increase the overall demand for more healthy products, drive the reformulation of foods by food manufacturers, and increase the availability of healthier foods to the general public $[25,26]$. Procurement policies have been indicated to be relatively inexpensive to implement, can encourage local production of foods if the policy requires sourcing food from local growers, and raise awareness about the importance of a healthy diet if coupled with education [26]. However, despite the potential for healthy food procurement interventions, they have not been broadly implemented, perhaps in part because of a lack of clear understanding of the impact of the policies that have been implemented. We conducted this review to identify healthy food procurement policies that have been evaluated for their impact on healthy eating and health outcomes. 


\section{Experimental Section}

A comprehensive search strategy was developed to identify articles that assessed the impact of healthy food procurement interventions. The databases PubMed (1964-27 July 2012), and Medline (1950-27 July 2012) were searched using the terms: "food procurement", "procurement policy", "procurement intervention", "food procurement policy", "healthy food catering”, "nutrition standards", "food procurement intervention" and "healthy food policy". Three reviewers examined titles and abstracts for randomized controlled trials and prospective and retrospective non randomized food procurement interventions that assessed the impact on: (1) nutrition related health indicators to include blood pressure, body mass index (BMI), body weight, blood lipids or glucose, (2) healthy food purchases by consumers, (3) consumption of healthier foods or (4) knowledge, attitudes or behaviors towards healthy foods. Full text articles were obtained and those that were not in English, did not involve humans, were based on data previously published, or were not full reports (i.e., abstracts) were excluded. The studies were classified into the primary site of the intervention (school, worksite, hospital, care home, correctional facility, government institution and remote community).

In addition, Google Scholar (July 2012) was searched and individuals at the World Health Organization (WHO), Pan American Health Organization (PAHO), Department of Health — Nutrition Branch in England, Centers for Disease Control and Prevention (CDC) in the USA, New York City Department of Health and Mental Hygiene, Heart Foundation in Australia, Government of New Zealand, and the Public Health Agency of Canada were contacted to determine if there were government interventions that may not have been published. These "grey" literature documents included government publications, recently completed studies, or unpublished materials. The references of publications were searched for additional relevant citations.

\section{Results and Discussion}

The PubMed database search retrieved 18,054 citations references while the Medline search retrieved 65,056 citations (Figure 1). The searches identified 83,110 citations when duplicate citations were excluded. One hundred and seventy seven full articles were reviewed, and, of these, 34 were found to meet the inclusion criteria of this review. The selected articles were placed into intervention categories based on setting as detailed below.

\subsection{Interventions in Schools}

Multiple healthy food policies for schools have been developed (Table 1). In 2008, England introduced a national regulation that requires all primary schools to use a healthy food procurement standard for foods throughout the school day [28-30]. These regulations impacted 136 primary schools and improved the purchases of fruits, vegetables, and salads by $15 \%$, and reduced processed foods high in sodium, fats, and sugars by $12 \%$ (e.g., French fries, pizza, and cookies) [28]. Following implementation, $74 \%$ of students indicated a greater desire for healthier foods, and there was a $15 \%$ increase in the purchase of healthier foods in cafeterias from 2006 to 2009 (Table 2) [28]. These improvements may also be attributed in part to concurrent educational programs that emphasized the importance of a healthy diet. In 2011, the Department of Education implemented a 
similar healthy food program in English secondary schools (Table 2) [31]. Dietary intake data was collected for 6,000 secondary schools students from 79 schools. The food procurement intervention reduced the sodium (18\%), sugar (4\%), and fat (5\%) content of several foods served in the participating schools. Analysis of dietary intake among students found a $16 \%$ reduction in energy intake, $27 \%$ reduction in fat, $18 \%$ reduction in sodium, and $37 \%$ reduction in sugar intake (Table 1) [32].

Figure 1. Selection of articles for review*.

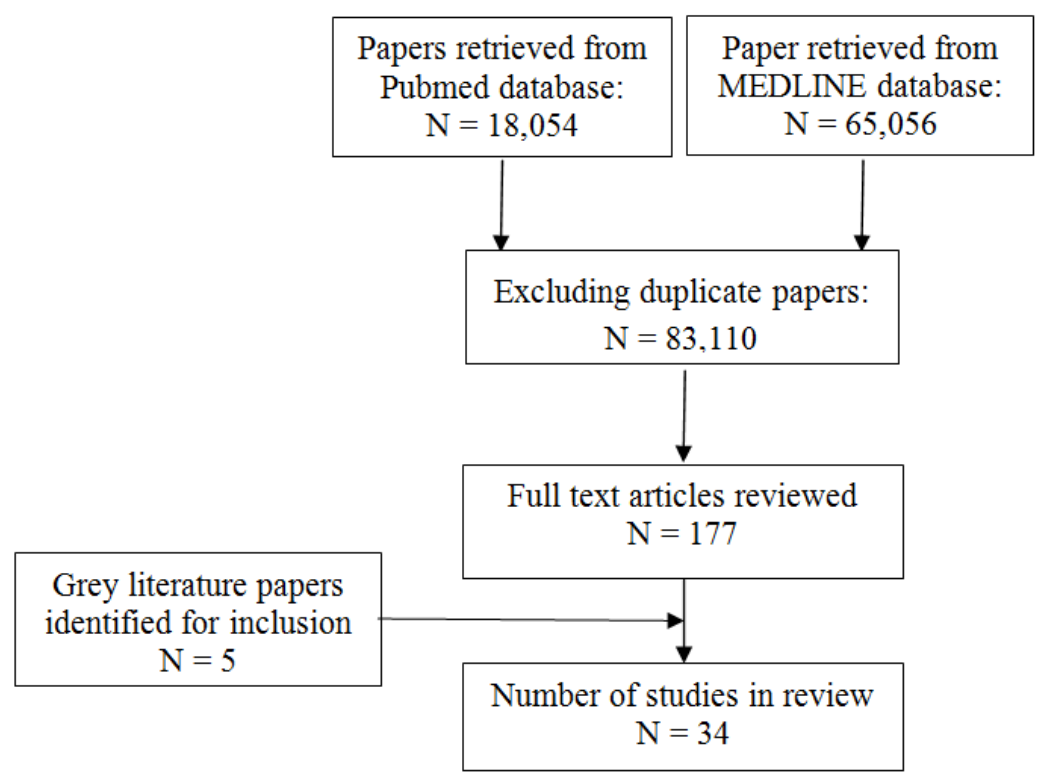

Notes: * Studies that were included if they were: (1) randomized controlled trials, prospective and retrospective non randomized food procurement interventions that assessed the impact on: (a) nutrition related health indicators to include blood pressure, body mass index (BMI), body weight, blood lipids or glucose, (b) healthy food purchases by consumers, (c) consumption of healthier foods or (d) knowledge, attitudes or behaviors towards healthy foods, and (2) full text articles, written in English. Studies that were duplicate publications and did not involve humans were excluded.

"The Fresh Program" in California, USA encouraged the growth and use of local foods rather than processed foods, provided funding opportunities to small and medium sized farms, and educated students about the importance of a healthy diet [33]. The "Fresh Program" resulted in a 58\% increase in fruit and vegetable sales, and $65 \%$ of students selected healthier menu items over foods high in fat, sugar and sodium (Table 1) [33].

In 2005, British Columbia Canada, introduced Guidelines for Food and Beverage Sales in BC Schools, which has led to $50 \%$ of schools eliminating foods that are "not recommended" by this program (e.g., soups with $>750 \mathrm{mg}$ of sodium per serving) [34]. A similar evaluation performed in 2007 found that schools who had yet to totally eliminate "not recommended" foods had reduced them under $20 \%$ of the total food sold in school vending machines and cafeterias [34]. California implemented a school-based program, and found that approximately $67 \%$ of schools were compliant with state standards, but no evaluation of changes in food intake pre- and post-intervention was performed [35-37].

There have been additional evaluations of healthy food procurement interventions in school settings using different methodologies (Table 1) [26-28,31,33,38-52]. Each of these studies had variations in 
sample size, age of students, duration, and educational component, and one included an intervention to promote physical activity. Despite these variations, all the food procurement interventions in school settings demonstrated increases in healthy food purchasing patterns (Table 1).

Many of the school interventions that also included an education component were effective at increasing the intake of healthy foods and decreasing the intake of foods high in fat, sodium, and sugar. Two studies that assessed health outcomes found a reduction in blood pressure and BMI $[39,42]$. In these studies, procurement of food involved providing greater quantities and lowering the price of healthy foods in cafeterias and vending machines. The studies were implemented without any perceived barriers.

Table 1. Healthy Food Procurement Programs in Schools.

\begin{tabular}{|c|c|c|c|}
\hline Study and Year & Study Description & Intervention(s) & $\begin{array}{l}\text { Post-intervention Outcome(s) } \\
\text { and Notable Findings }\end{array}$ \\
\hline $\begin{array}{l}\text { School Food Trust } \\
2009[28]\end{array}$ & $\begin{array}{l}\text { At } 136 \text { primary } \\
\text { schools in England, } \\
\text { dietary intake was } \\
\text { assessed and } \\
\text { compared with } 2005 \\
\text { survey results. }\end{array}$ & $\begin{array}{l}\text { Increased provision of healthy } \\
\text { foods and decreased the } \\
\text { availability of foods high in } \\
\text { sodium, fat, and sugar. }\end{array}$ & $\begin{array}{l}\text { Consistent benefits from } 2005 \text { to } 2009 \\
\text { and included decreased sugar, fat, } \\
\text { and saturated fat intake. Further, these } \\
\text { lunches in } 2009 \text { contained almost } \\
\text { one-third less sodium compared } \\
\text { with } 2005 \text {. }\end{array}$ \\
\hline $\begin{array}{l}\text { School Food Trust } \\
2011[31]\end{array}$ & $\begin{array}{l}\text { At } 80 \text { secondary } \\
\text { schools in England, } \\
\text { dietary intake was } \\
\text { assessed and } \\
\text { compared with } 2004 \\
\text { results [32]. }\end{array}$ & $\begin{array}{l}\text { Increase provision of healthy } \\
\text { foods and decreased the } \\
\text { availability of unhealthy foods } \\
\text { high in sodium, fat, and sugar. }\end{array}$ & $\begin{array}{l}\text { The average meal contained }>30 \% \text { less } \\
\text { saturated fat, total fat, sodium and } \\
\text { sugar and } 50 \% \text { more vitamin A than in } \\
2004 \text { and there was a } 6 \% \text { increase in } \\
\text { F\&V intake since then. }\end{array}$ \\
\hline $\begin{array}{l}\text { School Food Trust } \\
2004[32]\end{array}$ & $\begin{array}{l}\text { At } 79 \text { secondary } \\
\text { schools in England, } \\
\text { dietary intake was } \\
\text { assessed. }\end{array}$ & $\begin{array}{l}\text { Improved the nutritional quality } \\
\text { of foods served in the schools } \\
\text { and performed surveys. }\end{array}$ & $\begin{array}{l}\text { On average, the intervention reduced } \\
\text { dietary total fat, saturated fat, sugar, } \\
\text { sodium, and energy intake by } \\
27 \%, 23 \%, 37 \%, 18 \% \text {, and } 16 \% \text {, } \\
\text { respectively, in the schools. } \\
\text { Survey results were with } 2011 \\
\text { results }[31] \text {. }\end{array}$ \\
\hline $\begin{array}{l}\text { Joshi et al. } \\
2005[33]\end{array}$ & $\begin{array}{l}\text { This report showcases } \\
\text { innovative farm to } \\
\text { school programs from } \\
\text { around the USA to } \\
\text { include eight case } \\
\text { studies. }\end{array}$ & $\begin{array}{l}\text { Predominantly provision of } \\
\text { fresh foods from local farms } \\
\text { along with education } \\
\text { though innovative strategies } \\
\text { are detailed. }\end{array}$ & $\begin{array}{l}\text { Results varied with each state's } \\
\text { intervention(s). In California, } \\
65 \% \text { of students chose healthier menu } \\
\text { items over meals high in fat, sugar and } \\
\text { sodium and increased intake of F\&V } \\
\text { by } 58 \% \text {. There were an estimated } \\
950 \text { "Fresh" programs in the USA } \\
\text { by } 2006 .\end{array}$ \\
\hline
\end{tabular}


Table 1. Cont.

\begin{tabular}{|c|c|c|c|}
\hline Study and Year & Study Description & Intervention(s) & $\begin{array}{l}\text { Post-intervention Outcome(s) } \\
\text { and Notable Findings }\end{array}$ \\
\hline $\begin{array}{l}\text { Simons-Morton et al. } \\
1991[38]\end{array}$ & $\begin{array}{l}\text { Four elementary } \\
\text { schools for } \\
\text { K-4th grade students } \\
\text { in Texas (USA) with } \\
\text { two being controls } \\
\text { evaluated the impact } \\
\text { of a school-based } \\
\text { program on } \\
\text { improving diet and } \\
\text { physical activity. }\end{array}$ & $\begin{array}{l}\text { The three intervention } \\
\text { components were classroom } \\
\text { education (Go For Health } \\
\text { Curriculum), physical activity } \\
\text { (Children's Active Physical } \\
\text { Education), and low fat/low } \\
\text { sodium school lunches } \\
\text { (New School Lunch). }\end{array}$ & $\begin{array}{l}\text { The two intervention schools had } \\
\text { decreased total fat }(15.5 \% ; 10.4 \%) \text {, } \\
\text { saturated fat }(31.7 \% ; 18.8 \%) \text {, } \\
\text { and sodium }(40.3 \% ; 53.6 \%) \text {. } \\
\text { Physical activity increased from less } \\
\text { than } 10 \% \text { class time to } 40 \% \text { of class } \\
\text { time. Adoption of such programs in } \\
\text { other schools may be a challenge. }\end{array}$ \\
\hline $\begin{array}{l}\text { Ellison et al. } \\
1989 \text { [39] }\end{array}$ & $\begin{array}{l}\text { Food service workers } \\
\text { ate two high schools } \\
\text { in Massachusetts and } \\
\text { New Hampshire } \\
\text { modified preparation } \\
\text { of foods served at } \\
\text { dining halls. }\end{array}$ & $\begin{array}{l}\text { Increased availability of healthier } \\
\text { food through the food service } \\
\text { providers and assessed in all } \\
\text { students taking a science course. }\end{array}$ & $\begin{array}{l}\text { Reduced sodium intake by } 15 \%-20 \% \\
\text { and saturated fat intake by } 20 \% \text {. } \\
\text { The lower sodium intake over a school } \\
\text { year resulted in lower blood pressure } \\
\text { among students receiving the } \\
\text { intervention. Intervention was well } \\
\text { received by workers and students. }\end{array}$ \\
\hline $\begin{array}{l}\text { Jeffrey et al. } \\
1994[40]\end{array}$ & $\begin{array}{l}\text { Cafeteria at a } \\
\text { university office } \\
\text { building housing } 700 \\
\text { employees in } \\
\text { Minnesota (USA). }\end{array}$ & $\begin{array}{l}\text { Increased availability and } \\
\text { reduced price of fruit and } \\
\text { salads in a school cafeteria and } \\
\text { assessed by daily sales. }\end{array}$ & $\begin{array}{l}\text { Three-fold increase in the sale of fruit } \\
\text { and salad after reducing the price by } \\
50 \% \text { over a } 3 \text {-wk period. } \\
\text { Women were more prone to make } \\
\text { more nutritious purchases. }\end{array}$ \\
\hline $\begin{array}{l}\text { French } \text { et al. } \\
2001 \text { [41] } \\
\text { (Also in Table 2) }\end{array}$ & $\begin{array}{l}\text { Examined the impact } \\
\text { of pricing and } \\
\text { promotion of low-fat } \\
\text { snacks in vending } \\
\text { machines at } \\
12 \text { worksites and } \\
12 \text { schools in } \\
\text { Minnesota (USA) } \\
\text { over a } 12 \text {-month } \\
\text { period. }\end{array}$ & $\begin{array}{l}\text { Low-fat snacks added to } \\
55 \text { vending machines were } \\
\text { subject to four pricing } \\
\text { conditions and three } \\
\text { promotional conditions and } \\
\text { sales were tracked. }\end{array}$ & $\begin{array}{l}\text { Price reductions of } 10 \%, 25 \%, \\
\text { and } 50 \% \text { were associated with } \\
\text { significant increases in sales of } \\
\text { low-fat snacks in adults and } \\
\text { adolescents. Profits per vending } \\
\text { machine were not impacted and } \\
\text { promotional signage may have } \\
\text { had slight effect. }\end{array}$ \\
\hline $\begin{array}{l}\text { Saksvig et al. } \\
2005[42]\end{array}$ & $\begin{array}{l}\text { Ojibway-Cree First } \\
\text { Nations 3rd, 4th and } \\
\text { 5th grades students } \\
\text { with school-based } \\
\text { program delivered at } \\
\text { the Sandy Lake } \\
\text { School in northern } \\
\text { Canada assessed at } \\
\text { baseline and one year } \\
\text { later at follow-up. }\end{array}$ & $\begin{array}{l}\text { Culturally appropriate diabetes } \\
\text { prevention program that } \\
\text { banned high-fat and high-sugar } \\
\text { snack foods and provided a } \\
\text { healthier lunch. Included } \\
\text { education on diet and physical } \\
\text { activity with community } \\
\text { support. }\end{array}$ & $\begin{array}{l}\text { This program was associated with } \\
\text { improved dietary knowledge, dietary } \\
\text { self-efficacy, and understanding of the } \\
\text { psychosocial factors related to healthy } \\
\text { eating and dietary fiber intake of } \\
\text { students in a remote First Nations } \\
\text { community. The intake of energy from } \\
\text { total fat decreased significantly by } 2 \% \\
\text { after one year. }\end{array}$ \\
\hline
\end{tabular}


Table 1. Cont.

\begin{tabular}{|c|c|c|c|}
\hline Study and Year & Study Description & Intervention(s) & $\begin{array}{l}\text { Post-intervention Outcome(s) } \\
\text { and Notable Findings }\end{array}$ \\
\hline $\begin{array}{l}\text { Auld et al. } \\
1998[43]\end{array}$ & $\begin{array}{l}\text { Comprehensive, } \\
\text { 4-yr program in three } \\
\text { Denver, CO (USA) } \\
\text { elementary schools } \\
\text { aimed at increasing } \\
\text { consumption of whole } \\
\text { grains, F\&V with } \\
\text { nutrition education. }\end{array}$ & $\begin{array}{l}\text { Integrated Nutrition Project } \\
\text { included } 24 \text { weekly hands-on, } \\
\text { teacher led activities; } \\
\text { six parent-taught lunchroom } \\
\text { mini-lesson. }\end{array}$ & $\begin{array}{l}\text { Students in treatment classrooms } \\
\text { achieved significantly greater gains in } \\
\text { knowledge and self-efficacy on food } \\
\text { preparation and F\&V consumption. } \\
\text { Integrated approach with education } \\
\text { and healthy food procurement may } \\
\text { increase desire for healthier foods. }\end{array}$ \\
\hline $\begin{array}{l}\text { French et al. } \\
2004[44]\end{array}$ & $\begin{array}{l}20 \text { secondary schools } \\
\text { in Minnesota } \\
\text { participated over two } \\
\text { years with a portion } \\
\text { serving as controls. }\end{array}$ & $\begin{array}{l}\text { Environmental intervention in } \\
\text { school cafeterias where they } \\
\text { increased availability of lower } \\
\text { fat foods and implemented } \\
\text { student-based promotions. }\end{array}$ & $\begin{array}{l}\text { There was a significant increase }(35 \%) \\
\text { in the sales of lower-fat foods in the } \\
\text { intervention group and a significant } \\
\text { increase in lower-fat foods in the al a } \\
\text { carte product mix. }\end{array}$ \\
\hline $\begin{array}{l}\text { Perry et al. } \\
1998[45]\end{array}$ & $\begin{array}{l}20 \text { primary schools in } \\
\text { Minnesota used a } \\
\text { multi-component } \\
\text { approach to increase } \\
\text { F\&V consumption in } \\
4 \text { th/5th grade students } \\
\text { over a } 2 \text { year period. }\end{array}$ & $\begin{array}{l}\text { The 5-a-Day Power Plus } \\
\text { Program included behavioral } \\
\text { curricula in the classroom, } \\
\text { parental involvement, school } \\
\text { food changes, and industry } \\
\text { involvement. }\end{array}$ & $\begin{array}{l}\text { The program significantly increased } \\
\text { lunchtime F\&V consumption; fruit } \\
\text { consumption; vegetable consumption } \\
\text { among girls. }\end{array}$ \\
\hline $\begin{array}{l}\text { Perry et al. } \\
2004[46]\end{array}$ & $\begin{array}{l}\text { The project was } \\
\text { performed at } \\
26 \text { elementary schools } \\
\text { (grades } 1-4 \text { ) in } \\
\text { Minnesota (USA) } \\
\text { over two consecutive } \\
\text { school years. }\end{array}$ & $\begin{array}{l}\text { The Cafeteria Power Plus } \\
\text { project sought to increase the } \\
\text { daily availability, attractiveness, } \\
\text { and encouragement for F\&V } \\
\text { with kick-offs, samplings, and } \\
\text { challenge weeks. Training of } \\
\text { food-service staff and cook } \\
\text { managers was ongoing. }\end{array}$ & $\begin{array}{l}\text { Students in the intervention schools } \\
\text { significantly increased their total fruit } \\
\text { intake. Process measures indicated that } \\
\text { verbal encouragement by food-service } \\
\text { staff was associated with outcomes. } \\
\text { The outcomes suggest that } \\
\text { multicomponent interventions are } \\
\text { more powerful than cafeteria programs } \\
\text { alone with this age group. }\end{array}$ \\
\hline $\begin{array}{l}\text { Lytle et al. } \\
2006 \text { [47] }\end{array}$ & $\begin{array}{l}\text { As part of the TEENS } \\
\text { study, } 16 \text { middle } \\
\text { schools in Minnesota } \\
\text { (USA) with } \\
\text { approximately } 3,600 \\
\text { students in the eight } \\
\text { intervention schools } \\
\text { were exposed to a } \\
\text { multi-component } \\
\text { intervention from } \\
\text { 1997-2000. }\end{array}$ & $\begin{array}{l}\text { The TEENS intervention } \\
\text { included classroom-based } \\
\text { curricula, family newsletters, } \\
\text { and changes in the school food } \\
\text { environment including } \\
\text { increasing more healthful } \\
\text { options on a la carte and on the } \\
\text { school lunch line top increase } \\
\text { the availability of F\&V and } \\
\text { lower fat foods in homes and } \\
\text { schools. }\end{array}$ & $\begin{array}{l}\text { Parents of students in intervention } \\
\text { schools reported making significantly } \\
\text { more healthy food choices when } \\
\text { shopping than parents of students in } \\
\text { control schools. Compared to control } \\
\text { schools, intervention schools offered } \\
(p=0.04) \text { and sold ( } p=0.07) \text { a } \\
\text { significantly higher proportion of } \\
\text { healthier foods on a la carte. }\end{array}$ \\
\hline
\end{tabular}


Table 1. Cont.

\begin{tabular}{|c|c|c|c|}
\hline Study and Year & Study Description & Intervention(s) & $\begin{array}{l}\text { Post-intervention Outcome(s) } \\
\text { and Notable Findings }\end{array}$ \\
\hline $\begin{array}{l}\text { Reynolds et al. } \\
2000 \text { [48] }\end{array}$ & $\begin{array}{l}28 \text { elementary schools } \\
\text { in Alabama (USA) } \\
\text { assessed the effects of } \\
\text { a dietary intervention } \\
\text { program in 4th graders } \\
\text { over two years based } \\
\text { on diet and } \\
\text { psychosocial variables. }\end{array}$ & $\begin{array}{l}\text { The High } 5 \text { project included } \\
\text { classroom, parent, and cafeteria } \\
\text { intervention components that } \\
\text { increased availability of } \mathrm{F} \& \mathrm{~V} \text { in } \\
\text { alliance with education. }\end{array}$ & $\begin{array}{l}\text { F\&V consumption was significantly } \\
\text { higher in the intervention group } \\
\text { children at follow-up one and two } \\
\text { when compared to children in the } \\
\text { control group. F\&V consumption by } \\
\text { parents in the intervention group was } \\
\text { significantly higher at follow-up one } \\
\text { when compared to control parents. }\end{array}$ \\
\hline $\begin{array}{l}\text { Osganian et al. } \\
1996[49]\end{array}$ & $\begin{array}{l}\text { The CATCH Eat } \\
\text { Smart Program was } \\
\text { implemented at } 56 \\
\text { schools in four states } \\
\text { over } 2.5 \text { years and } \\
\text { assessed school menu, } \\
\text { recipe, and vendor } \\
\text { product information on } \\
\text { five consecutive days } \\
\text { on three occasions. }\end{array}$ & $\begin{array}{l}\text { Targeted school food service } \\
\text { staff through education on } \\
\text { making positive changes in the } \\
\text { nutrient quality of school meals } \\
\text { and base them on national } \\
\text { dietary goals to lower the total } \\
\text { fat, saturated fat, and sodium } \\
\text { content of school meals. }\end{array}$ & $\begin{array}{l}\text { There was a significantly greater mean } \\
\text { reduction in the calories from total fat } \\
\text { and saturated fat in intervention } \\
\text { compared with control school from } \\
\text { baseline to follow-up. } \\
\text { Though total caloric consumption } \\
\text { decreased by } 683 \mathrm{kcal} n \text { the } \\
\text { intervention group it was still one-third } \\
\text { above the Recommended Dietary } \\
\text { Allowances for this age group. }\end{array}$ \\
\hline $\begin{array}{l}\text { Bartholomew \& } \\
\text { Jowers. } 2006 \text { [50] }\end{array}$ & $\begin{array}{l}\text { Two elementary } \\
\text { schools of similar size } \\
\text { and demographic data } \\
\text { in Texas (USA) were } \\
\text { used for a two-phase } \\
\text { study evaluating an } \\
\text { intervention to increase } \\
\text { selection of low- and } \\
\text { moderate- fat entrees } \\
\text { over two semesters. }\end{array}$ & $\begin{array}{l}\text { In Phase } 1 \text {, the rotation of } \\
\text { existing entrees was modified } \\
\text { such that one of three entree } \\
\text { choices was low or moderate in } \\
\text { fat. In Phase } 2 \text {, the number of } \\
\text { competing high-fat entrees was } \\
\text { reduced from two choices to one. }\end{array}$ & $\begin{array}{l}\text { In Phase } 1 \text { in the intervention school, } \\
\text { the number of days that a low-fat } \\
\text { entree was offered increased by } \\
70 \% \text {, with no increase in the rate of } \\
\text { selection of the lower moderate-fat } \\
\text { entrees. In Phase } 2 \text {, both low- and } \\
\text { moderate-fat entrees were selected at a } \\
\text { significantly higher rate in the } \\
\text { intervention school ( } 32.1 \% \text { and } 26.4 \% \text {, } \\
\text { respectively) than the control school } \\
\text { ( } 13.8 \% \text { and } 7.5 \%, \text { respectively). }\end{array}$ \\
\hline $\begin{array}{l}\text { Belansky et al. } \\
2010[51]\end{array}$ & $\begin{array}{l}\text { The project surveyed } \\
45 \text { low-income, rural } \\
\text { elementary schools in } \\
\text { Colorado one year } \\
\text { before and after a } \\
\text { healthy eating, } \\
\text { wellness policy } \\
\text { mandated in } 2006 \text {. }\end{array}$ & $\begin{array}{l}\text { The What's Working project } \\
\text { described the influence of a } \\
\text { mandated Local Wellness Policy } \\
\text { (LWP) to identify impacts, } \\
\text { opportunities, and barriers. }\end{array}$ & $\begin{array}{l}\text { Three improvements were associated } \\
\text { with the new policy, namely: increased } \\
\text { percentage of schools with policies } \\
\text { stipulating healthy items be offered in } \\
\text { classroom parties ( } 21.4 \% \text { in } 2005 \text { vs. } \\
48.7 \% \text { in } 2007) \text {, daily fresh fruit be } \\
\text { offered in lunchrooms ( } 0.80 \text { choices in } \\
2005 \text { vs. } 1.15 \text { choices in } 2007) \text {, } \\
\text { and skinless poultry be used } \\
\text { ( } 27 \% \text { in } 2005 \text { vs. } 59 \% \text { in } 2007) \text {. }\end{array}$ \\
\hline
\end{tabular}


Table 1. Cont.

\begin{tabular}{|c|c|c|c|}
\hline Study and Year & Study Description & Intervention(s) & $\begin{array}{l}\text { Post-intervention Outcome(s) } \\
\text { and Notable Findings }\end{array}$ \\
\hline $\begin{array}{l}\text { Anderson et al. } \\
2005[52]\end{array}$ & $\begin{array}{l}\text { Investigated the impact } \\
\text { of a school-wide } \\
\text { nutrition education } \\
\text { program in primary } \\
\text { schools in Scotland at } \\
\text { baseline and } 9 \text { months. } \\
\text { Dietary and attitude } \\
\text { assessments of } \\
\text { children aged 6-7 and } \\
10-11 \text { were performed. }\end{array}$ & $\begin{array}{l}\text { Increased provision of } \mathrm{F} \& \mathrm{~V} \text { and } \\
\text { provided point-of-purchase } \\
\text { marketing materials, education } \\
\text { materials, newsletters, } \\
\text { and teacher information. }\end{array}$ & $\begin{array}{l}\text { Children in the two intervention } \\
\text { schools had a significantly higher } \\
\text { average increase in fruit consumption } \\
\text { than those in two control schools. } \\
\text { No other changes in nutrient uptake } \\
\text { were detected. }\end{array}$ \\
\hline
\end{tabular}

\subsection{Interventions in Worksites}

A summary of effective strategies to increase healthy food intake in the workplace has been developed previously [53,54], and six articles on healthy food procurement in worksites were included in this review. A study at several worksites in Denmark incorporated education with healthy food procurement strategies and provided greater access to fruits and vegetables and found increased consumption of healthy foods by 70 grams per day [55]. Similarly, increasing the availability of healthy foods and educating staff about the importance of a healthy diet was an effective means of improving healthy food intake by up to $20 \%$ among staff at multiple worksites (Table 2) [56-58]. Two worksite interventions reduced the availability of unhealthy nutrients in workplace foods (e.g., energy from fat reduced by $30 \%$ and sodium by up to $65 \%$ per serving) while increasing healthier food options in a cafeteria and vending machines (Table 2) [41,59]. Reducing relative pricing on low-fat snacks was effective in increasing low-fat snack purchases from vending machines in adult and adolescent populations (Table 2) [41]. Further, when available and properly marketed, customers may accept healthy food options over unhealthy alternatives (Table 2) [41,59].

Table 2. Healthy Food Procurement Programs in Worksites

\begin{tabular}{|c|c|c|c|}
\hline Study and Year & $\begin{array}{l}\text { Study } \\
\text { Description }\end{array}$ & Intervention(s) & $\begin{array}{l}\text { Post-intervention Outcome(s) } \\
\text { and Notable Findings }\end{array}$ \\
\hline $\begin{array}{l}\text { Lassen et al. } \\
2004 \text { [55] }\end{array}$ & $\begin{array}{l}\text { Five worksites in } \\
\text { Denmark with } \\
\text { canteens promoted } \\
\text { healthier lunches with } \\
\text { an end point and } \\
\text { follow up data } \\
\text { collection. }\end{array}$ & $\begin{array}{l}\text { Implemented a continuous } \\
\text { quality improvement of canteen } \\
\text { lunches through a spectrum of } \\
\text { strategies to include increased } \\
\text { availability of healthy foods, } \\
\text { staff training, goal setting, } \\
\text { and support groups. }\end{array}$ & $\begin{array}{l}\text { On average across the five sites there } \\
\text { was } 70 \mathrm{~g} / \text { day/customer increase in the } \\
\text { intake of } \mathrm{F} \& \mathrm{~V} \text { intake at endpoint and a } \\
95 \mathrm{~g} / \text { day/customer increase four months } \\
\text { after endpoint. }\end{array}$ \\
\hline
\end{tabular}


Table 2. Cont.

\begin{tabular}{|c|c|c|c|}
\hline Study and Year & $\begin{array}{l}\text { Study } \\
\text { Description }\end{array}$ & Intervention(s) & $\begin{array}{l}\text { Post-intervention Outcome(s) } \\
\text { and Notable Findings }\end{array}$ \\
\hline $\begin{array}{l}\text { Beresford et al. } \\
2001[56]\end{array}$ & $\begin{array}{l}\text { Targeted } 28 \text { Seattle, } \\
\text { WA (USA) worksites } \\
\text { with cafeterias in } \\
\text { Seattle to increase } \\
\text { F\&V intake assessed } \\
\text { at baseline and } \\
\text { two-year follow-up. }\end{array}$ & $\begin{array}{l}\text { Seattle "5 a Day for Better } \\
\text { Health" is a simple message } \\
\text { encouraging people to eat more } \\
\text { F\&V which was launched at } 14 \\
\text { intervention worksites and } \\
\text { compared with } \\
14 \text { control worksites. }\end{array}$ & $\begin{array}{l}\text { Significantly higher intake of } F \& V \text { in the } \\
\text { intervention group after two years with } \\
0.3 \text { more servings than the control group. }\end{array}$ \\
\hline $\begin{array}{l}\text { Sorensen et al. } \\
1999 \text { [57] }\end{array}$ & $\begin{array}{l}22 \text { Community Health } \\
\text { Centers in } \\
\text { Massachusetts (USA) } \\
\text { implemented the } \\
\text { Treatwell 5-a-day } \\
\text { project to get } \\
\text { participants to } \\
\text { consume > five F\&V } \\
\text { servings per day. }\end{array}$ & $\begin{array}{l}\text { The program incorporated three } \\
\text { interventions, namely minimal } \\
\text { intervention, worksite } \\
\text { intervention, and worksite plus } \\
\text { family intervention which } \\
\text { included education components. }\end{array}$ & $\begin{array}{l}\text { Total intake increased by } 19 \% \text { in } \\
\text { worksite plus family group, } \\
7 \% \text { in worksite group, and } 0 \% \text { in } \\
\text { minimal intervention group. } \\
\text { Only } 23 \% \text { of all participants reported } \\
\text { consuming more than five servings per } \\
\text { day. Consumption of F\&V was directly } \\
\text { associated with level of household } \\
\text { support for healthy eating. }\end{array}$ \\
\hline $\begin{array}{l}\text { Sorensen et al. } \\
1998[58]\end{array}$ & $\begin{array}{l}24 \text { manufacturing } \\
\text { worksites in } \\
\text { Massachusetts (USA) } \\
\text { assessed the impact of } \\
\text { an integrated health } \\
\text { promotion effort. }\end{array}$ & $\begin{array}{l}\text { Implemented three intervention } \\
\text { components: joint } \\
\text { worker-management } \\
\text { participation in program } \\
\text { planning and implementation, } \\
\text { consultation with management } \\
\text { on worksite environment, and } \\
\text { health education. }\end{array}$ & $\begin{array}{l}\text { The intervention group had a reduced } \\
\text { intake of calories consumed as fat } \\
\text { ( } 2.3 \% \text { vs. } 1.5 \% \text { in control) and increased } \\
\text { intake of } \mathrm{F} \& \mathrm{~V} \text { ( } 10 \% \text { vs. } 4 \% \text { in control. }\end{array}$ \\
\hline $\begin{array}{l}\text { French } \text { et al. } \\
2001 \text { [41] } \\
\text { (Also in Table 1) }\end{array}$ & $\begin{array}{l}\text { Examined the impact } \\
\text { of pricing and } \\
\text { promotion of low-fat } \\
\text { snacks in vending } \\
\text { machines at } 12 \\
\text { worksites and } 12 \text { in } \\
\text { Minnesota (USA). }\end{array}$ & $\begin{array}{l}\text { Low-fat snacks added to } \\
55 \text { vending machines were } \\
\text { subject to four pricing } \\
\text { conditions and three } \\
\text { promotional conditions. Sales } \\
\text { and profits were tracked over a } \\
\text { 12-month period. }\end{array}$ & $\begin{array}{l}\text { Price reductions of } 10 \%, 25 \% \text {, } \\
\text { and } 50 \% \text { were associated with } \\
\text { significant increases in sales of low-fat } \\
\text { snacks in adults and adolescents. } \\
\text { Profits per vending machine were not } \\
\text { impacted and promotional signage may } \\
\text { have had slight effect. }\end{array}$ \\
\hline $\begin{array}{l}\text { Perlmutter et al. } \\
1997 \text { [59] }\end{array}$ & $\begin{array}{l}\text { Assessed acceptance of } \\
\text { more healthful entrees } \\
\text { in a Kansas (USA) } \\
\text { worksite cafeteria that } \\
\text { services est. } 200 \\
\text { employees per day } \\
\text { based on sales data, } \\
\text { nutrient analysis, } \\
\text { customer acceptability. }\end{array}$ & $\begin{array}{l}\text { Five phase study modified } \\
\text { entrees over a } 7 \text {-month period to } \\
\text { include less than } 30 \% \text { energy } \\
\text { from fat and less than } 1,000 \mathrm{mg} \\
\text { sodium per serving. A } \\
\text { marketing component identified } \\
\text { healthier food offerings. }\end{array}$ & $\begin{array}{l}\text { No significant difference in sales was } \\
\text { observed though customers may be more } \\
\text { willing to accept changes in flavor } \\
\text { attributes when they are identified as } \\
\text { healthful and include nutrient } \\
\text { information. }\end{array}$ \\
\hline
\end{tabular}




\subsection{Interventions in Hospitals, Care Homes, Correctional Facilities, Government Institutions and} Miscellaneous Settings

Outside of school and worksite settings, hospitals, care homes, correctional facilities, government institution, and a few miscellaneous settings have implemented healthy food policies and programs (Table 3). In Ireland, the impact of a structured catering initiative on food choices was evaluated in a hospital setting [60]. A cross-sectional comparison was made using a 24-hour dietary recall and questionnaire of participants aged 18-64 years in two hospitals; one implemented a catering initiative that promoted nutritious food and reduced sugar, fat, and salt, and the other was used as a control (Table 3) [60]. Overall, this study found that improving the dietary quality of menu items provided in hospitals can reduce the amount of unhealthy nutrients such as fat, sugar, and sodium in foods served to patients in a hospital setting by up to 30\% [60]. In England, the Food Standards Agency introduced healthy nutrition standards, to include reduced fat and increased fruit and vegetable intake, for persons $\geq 75$ years of age in residential and nursing care homes though outcomes in these settings have not been reported upon [61]. Yet, homebound, low-income seniors that were delivered healthy food baskets increased their intake of fruits and vegetables relative to a control group (Table 3) [62]. In addition, interventions have been introduced in some correctional facilities. For example, the Indiana Department of Correction (IDOC) and their food-service provider (ARAMARK Correctional Services) collaborated to create a new menu that substantially improved the dietary quality of foods in all 28 facilities across the state of Indiana in the United States (Table 3) [27].

Table 3. Healthy Food Procurement Programs in Hospitals, Care Homes, Correctional Facilities, Government Institutions, and Miscellaneous Settings.

\begin{tabular}{|c|c|c|c|}
\hline Study and Year & $\begin{array}{l}\text { Study } \\
\text { Description }\end{array}$ & Intervention(s) & $\begin{array}{l}\text { Post-intervention Outcome(s) } \\
\text { and Notable Findings }\end{array}$ \\
\hline $\begin{array}{l}\text { L'Abbé et al. } \\
2011[26]\end{array}$ & $\begin{array}{l}\text { Comprehensive } \\
\text { review on existing } \\
\text { healthy food } \\
\text { procurement policies } \\
\text { and programs. }\end{array}$ & $\begin{array}{l}\text { Details multiple } \\
\text { programs and their } \\
\text { interventions on healthy } \\
\text { food procurement } \\
\text { initiatives. }\end{array}$ & $\begin{array}{l}\text { Numerous successful food procurement programs } \\
\text { in Canada and Internationally are described to } \\
\text { include criteria (such as sodium limits) for healthy } \\
\text { foods and recommendations for a healthy food } \\
\text { procurement framework in Canada. }\end{array}$ \\
\hline $\begin{array}{l}\text { CDC } \\
2012[27]\end{array}$ & $\begin{array}{l}28 \text { correctional } \\
\text { facilities across } \\
\text { Indiana (USA). }\end{array}$ & $\begin{array}{l}\text { Implemented new menu } \\
\text { with } 20 \% \text { less sodium } \\
\text { than the previous diet. }\end{array}$ & $\begin{array}{l}\text { Successfully launched healthier food menu } \\
\text { statewide. Menu also increased servings of fruit in } \\
\text { place of baked desserts, averaging at least five } \\
\text { servings of F\&V per day. To help lower } \\
\text { cholesterol, the menu also serves no fried foods } \\
\text { and fewer high-fat menu items. }\end{array}$ \\
\hline $\begin{array}{l}\text { Geaney et al. } \\
2011[60]\end{array}$ & $\begin{array}{l}\text { Two public hospitals } \\
\text { in Ireland and } \\
\text { monitored food and } \\
\text { nutrient intake } \\
\text { monitored for } \\
\text { participants aged } \\
18-64 \text { in their } \\
\text { canteen. }\end{array}$ & $\begin{array}{l}\text { One of the two hospitals } \\
\text { implemented a catering } \\
\text { initiative designed to } \\
\text { provide nutritious foods } \\
\text { while reducing sugar, } \\
\text { fat, and salt intakes in } \\
\text { their canteen. }\end{array}$ & $\begin{array}{l}\text { Mean intakes of total sugars, total fat, saturated fat, } \\
\text { and salt were significantly lower in the intervention } \\
\text { hospital where } 72 \% \text { of respondents, compared with } \\
42 \% \text { in the control, complied with the } \\
\text { recommended under-3 daily servings of food high } \\
\text { in fat and sugar. In the intervention hospital, } 43 \% \text { of } \\
\text { respondents exceeded the recommended salt intake } \\
\text { of } 4-6 \mathrm{~g} / \text { day, compared with } 57 \% \text { in the control. }\end{array}$ \\
\hline
\end{tabular}


Table 3. Cont.

\begin{tabular}{|c|c|c|c|}
\hline Study and Year & $\begin{array}{l}\text { Study } \\
\text { Description }\end{array}$ & Intervention(s) & $\begin{array}{l}\text { Post-intervention Outcome(s) } \\
\text { and Notable Findings }\end{array}$ \\
\hline $\begin{array}{l}\text { Johnson et al. } \\
2004[62]\end{array}$ & $\begin{array}{l}480 \text { homebound, } \\
\text { low-income seniors } \\
\text { receiving Meals on } \\
\text { Wheels over } \\
4 \text { months in } \\
\text { Seattle, WA (USA) }\end{array}$ & $\begin{array}{l}\text { Increased access to fresh } \\
\text { F\&V via home delivery. }\end{array}$ & $\begin{array}{l}\text { Seniors receiving baskets consumed } 1.04 \text { more } \\
\text { servings than those in the control group. } \\
\text { The number of seniors consuming > five servings } \\
\text { per day increased by } 17 \% \text { from baseline. }\end{array}$ \\
\hline $\begin{array}{l}\text { Vander Wekken } \\
\& \text { Naylor } \\
2010[63]\end{array}$ & $\begin{array}{l}48 \text { local } \\
\text { governments in } \\
\text { British Columbia, } \\
\text { Canada, including } \\
12 \text { First Nations } \\
\text { addressed food } \\
\text { environments in } \\
142 \text { community } \\
\text { funded facilities. }\end{array}$ & $\begin{array}{l}\text { Evaluated food and } \\
\text { beverage framework in } \\
\text { local recreational settings } \\
\text { during 2008-2010. }\end{array}$ & $\begin{array}{l}\text { The initiative was successful at facilitating changes } \\
\text { in policy, practices, food provision, and patron } \\
\text { awareness. Key factors for change and challenges to } \\
\text { implementation were identified. }\end{array}$ \\
\hline $\begin{array}{l}\text { PSFPI } \\
2009[64]\end{array}$ & $\begin{array}{l}\text { Comprehensive } \\
\text { initiative for food } \\
\text { public institutions } \\
\text { such as schools, } \\
\text { hospitals, and } \\
\text { prisons in the } \\
\text { United Kingdom. }\end{array}$ & $\begin{array}{l}\text { Developed and } \\
\text { disseminated the PSFPI } \\
\text { report to encourage } \\
\text { consumption of locally } \\
\text { grown foods and } \\
\text { availability of healthy } \\
\text { foods and build } \\
\text { momentum for progress. }\end{array}$ & $\begin{array}{l}\text { Awareness of the program increased by } 24 \% \text { in } \\
2 \text { years; } 72 \% \text { of local authorities and } 69 \% \text { of } \\
\text { schools supported initiative; } 54 \% \text { of users } \\
\text { find the guidelines very useful or extremely } \\
\text { useful; constraints were identified. }\end{array}$ \\
\hline
\end{tabular}

Notes: CDC: Centers for Disease Control and Prevention; USA: United States of America; F\&V: fruit and vegetables; FSA: Food Standards Agency; PSFPI: Public Sector Food Procurement Initiative.

In February 2010, Alberta Health Services (AHS) introduced detailed dietary guidelines for AHS facilities for planning menus that meet nutritional targets from each food group and also nutrient criteria, such as the amount of sodium in a standard item [26]. The guidelines were divided into foods "recommended" and "not recommended" which included recommended servings per day of each category. For example, sodium levels in foods such as soups, frozen vegetables, yogurt, chocolate and soy milk, cookies, crackers, pancakes, waffles, cereal bars, and cheese were addressed across the province [26]. An evaluation in August 2010 found that the revised menu met the sodium target of $<3,000 \mathrm{mg} /$ day which is still higher than the dietary guidelines set in Canada [26]. The province continues to monitor the nutrient content of the menu and target comparisons twice per year. Similarly, British Columbia, Canada introduced healthy food policies in all recreational facilities and government buildings across the province, to include 12 First Nations, with successful impact [63]. Their healthy food policy interventions have led to $91 \%$ of vending machine food offerings being healthy compared to $35 \%$ prior to the intervention [63]. Meanwhile, community gardens in six California communities increased the consumption of fruits and vegetables as well as physical activity of participants (Table 3) [65]. 
In the United Kingdom, the 2002 Curry Report provided 100 recommendations designed to revive the role of farmed foods with consumers while achieving a more competitive and sustainable food supply [26]. Similarly, the "Public Sector Food Procurement Initiative (PSFPI)" was updated in 2011 by the Department of Environment, Food, and Rural Affairs to encourage the public sector to work with farmers to ensure that sustainable, healthy, and nutritious food is consumed in a variety of venues such as schools, hospitals, and correctional facilities [26,27]. Effective, best practices and barriers to food procurement were identified and guides and toolkits were developed to aid the broad implementation of healthy food procurement strategies (Table 3) [26,65]. In Norway, the price of foods (subsidies, taxes based on food nutritional quality) was found to be the primary method of influencing healthy choices [66]. Further, reducing the price of healthy foods such as grain, low fat milk, and vegetables and increasing prices for unhealthy foods such as sugar and butter was speculated to improve health outcomes [66].

\subsection{Interventions in Remote Communities}

The Healthy Foods North (HFN) program was a multilevel health intervention program aimed at improving the diet and nutritional status in six Inuit communities in the Canadian Arctic [67]. Specifically, the HFN intervention increased the availability of affordable/healthy foods (traditional foods, fruits, vegetables, and low sugar beverages), decrease the availability of less healthy foods and beverages (low in nutrients, high in fats and sugars), and promoted physical activity [67]. The HFN decreased intake of total calories and carbohydrate and average BMI by $2.6 \%$ [67]. Another healthy food intervention implemented in remote communities in Northern Canada is the Food Mail Project program [68]. This program aimed to reduce the cost of healthy perishable foods, increase nutrition education, and promote healthy foods in retail settings as a means to improve nutrition and health in the isolated communities [68]. An analysis of household surveys indicated that there was an increase in the purchase of fresh/frozen fruits and vegetables, milk, and eggs across all communities, and, in some cases, there was also an increase in the sale of other foods such as cheese and yogurt [68]. Both the HFN and Food Mail Project demonstrated that increased access to and consumption of quality, healthy food is achievable in remote communities where there are considerable logistical challenges though behavior change occurred slowly [67,68]. In 2005, a "Retail Based Nutrition Intervention" promoted healthier grocery store environments in Northern, isolated First Nations and Inuit communities in Canada [69]. By improving the availability and affordability of 32 targeted healthy foods while disseminating educational resources, the program found an initial increase in healthy food sales but that positive impact was not maintained after the promotion activities ended [69].

\subsection{Discussion}

Where evaluated, healthy food procurement programs found in this review were nearly always effective at increasing availability of healthier food and decreasing that of less healthy food; contributing to the increased purchases of healthier foods and lower purchases of food high in fat, sodium and sugar. Further, some interventions that included a health parameter as an outcome, found that healthy food uptake led to improvements in health outcomes (blood pressure and BMI) $[39,42]$. 
Although poorly documented in most studies, some interventions were "popular", some improved attitudes towards healthy eating, and some observed increases in total food sales as well as that of healthier foods. Health economic modeling from Los Angeles suggested that an effectively and broadly implemented government healthy food procurement policy could reduce disease rates and health costs while one of the interventions noted substantive cost advantages [36,70]. Our review has found evidence supporting the effectiveness of healthy food procurement policies at increasing healthy eating in a variety of settings.

There are, however, multiple limitations to the positive conclusions of this review. There were limited interventions in remote communities and no interventions found in low and middle income countries (LMIC). Most of the studies in this review were from the UK, Canada and USA and were limited to settings where the populations are relatively 'captive' with very few interventions in community or commercial settings. It is possible that in 'free living' situations (e.g., outside public institutions such as schools or hospitals) people will simply purchase food elsewhere. In the evaluated studies, additional health or policy interventions were often included with healthy food procurement interventions. These ancillary interventions often included educational programs (in schools, through public workshops, and online programs), price reductions or subsidies for healthy foods, and in one study, a physical activity program was included [38]. These interventions seemed to increase the impact of the food procurement policy and may be important success factors. It was not possible to assess the impact of food procurement separately from the ancillary interventions.

Another limitation to this review was the difficulty in locating studies evaluating food procurement policies. These policies are often implemented by governments with the outcomes potentially not being published, (even when indicated they are being assessed) or published in less accessible "grey" literature. It is likely that our search for policy evaluations missed several studies. The authors tried to mitigate this likelihood by directly contacting multiple experts including those in government and the WHO. Similarly, it is possible that the restricted nature of the search terms used in databases excluded studies that could have been included in the review. Lastly, we cannot exclude that there is a publication bias in the studies we identified.

We did not find any unsuccessful policy interventions. However, the Canadian media in 2012 released a story of an organized student protest relating to a provincial government health food procurement policy. Gum, coffee, chocolate, French fries, soda, pizza, and other foods were removed from schools, which has resulted in opposition from students who protested for the re-introduction of these foods, arguing that the policy has removed their freedom of choice [71]. The applicability of healthy food procurement policies to communities and in commercial settings, the barriers and challenges to the policies, long term impact on food purchases and consumption, costs of the intervention, sustainability, need for and usefulness of ancillary healthy eating policies (e.g., education and costing of food), and the utility of food procurement policy intervention in LMIC represent some future policy research needs. Increased priority funding from national funding organizations to support research on how to improve healthy eating such as healthy food procurement policies are needed. Such studies could include large scale randomized controlled trials with health outcomes and economic analysis as critical outcomes.

Healthy food procurement policies may be implemented for a variety of reasons in addition to having a direct impact on food purchases. Healthy food procurement policies have been indicated to 
increase the capacity of the food industry to produce healthy foods or to reformulate product lines to be healthier. This may only be a factor for policy interventions that affect large populations (e.g., national or regional government, large employer or bulk food procurer such as a major grocery store chain). Our review did not find any evaluations of the impact of policy on food manufacturers. Apart from the impact on health outcomes, in many countries food procurement is implemented to strengthen the local agriculture industry and or to reduce the overall costs of food purchases and the health impact is secondary. These latter purposes were not evaluated in this analysis but represent potential, additional rationale for introducing a healthy food procurement policy. It is also recommended that healthy food procurement policies are made necessary for schools, employers and governments to be internally consistent with the stated public policies relating to the health of those who consume the food they procure. Governments almost universally advocate healthy eating, schools teach students about healthy eating, and are in part responsible for students' wellbeing, while hospitals have responsibility for improving the health of those they care for and employers often have policy and priorities for creating healthy, safe workplaces. Procuring unhealthy food especially for relatively captive populations in these settings may be inconsistent with stated goals, priorities or other policies and has potential to undermine the credibility of the procuring organization.

\section{Conclusions}

Although many research questions remain about healthy food procurement policies, our review directly supports implementation of such policy in schools, worksites, and government institutions. Additional settings where people have limited eating options (hospitals, care homes, correctional facilities, military bases, and remote communities) would also likely to be able to introduce policy and successfully impact healthy eating. In the absence of contradictory evidence or rationale, we recommend broadly implementing (and evaluating) healthy food procurement policy for all settings where food is purchased by government or non-government organizations. Prior or simultaneous implementation of ancillary education about healthy eating and supportive pricing policy are likely to be critical success factors. Several documents have been developed to aid and encourage the uptake of healthy food procurement policies in different settings [24,27,28,31,54].

\section{Acknowledgments}

We would like to thank individuals from government departments and organizations who provided us with access to "grey" literature documents that were used for the purposes of this review, along with their editorial comments to a draft of the manuscript. This review article was funded in part by the Canadian Institutes of Health Research.

\section{Author Contributions}

Norm R. C. Campbell oversaw the systematic review and also contributed to the literature review and data extraction. Mark L. Niebylski, Tammy Lu, Patrick A. Twohig conducted the literature and data extraction and drafting of the manuscript. All authors were involved in the design of the study and review of the manuscript. 


\section{Conflicts of Interest}

The authors have no conflicts of interest to disclose.

\section{References}

1. Morgan, K.; Sonnino, R. Empowering consumers: The creative procurement of school meals in Italy and the UK. Int. J. Const. Stud. 2006, 1-7.

2. Webster, J.L.; Dunford, E.K.; Hawkes, C.; Neal, B.C. Salt reduction initiatives around the world. J. Hypertens. 2011, 29, 1043-1050.

3. He, F.J.; MacGregor, G. A comprehensive review on salt and health and current experience of worldwide salt reduction programmes. J. Hum. Hypertens. 2009, 23, 363-384.

4. Cutler, J.A.; Follmann, D.; Alexander, P.S. Randomized trials of sodium reduction: An overview. Amer. J. Clin. Nutr. 1997, 65, S643-S651.

5. Cook, N.R.; Cutler, J.A.; Obarzanek, E.; Buring, J.E.; Rexrode, K.M.; Kumanyika, S.K.; Appel, L.J.; Whelton, P.K. Long term effects of dietary sodium reduction on cardiovascular disease outcomes: Observational follow-up of the trials of hypertension prevention (TOHP). Brit. Med. J. 2007, 334, S885-S888.

6. CDC Grand Rounds: Dietary Sodium Reduction-Time for Choice, Centers for Disease Control and Prevention. Available online: http://www.cdc.gov/mmwr/preview/mmwrhtml/mm6105a2.htm (accessed on 21 February 2014).

7. Otsuka, R.; Kato, Y.; Imai, T.; Ando, F.; Shimokata, H. Decreased salt intake in Japanese men aged 40 to 70 years and women aged 70 to 79 years: An 8-year longitudinal study. J. Amer. Diet. Assn. 2011, 111, 844-850.

8. Millett, C.; Laverty, A.A.; Stylianou, N.; Bibbins-Domingo, K.; Pape, U.J. Impacts of a national strategy to reduce population salt intake in England: Serial cross sectional study. PLoS Clin. Trials 2012, 7, S1-S7.

9. He, F.J.; Appel, L.J.; Cappuccio, F.P.; de Wardener, H.E.; MacGregor, G.A. Does reducing salt intake increase cardiovascular mortality? Kidney Int. 2011, 80, 696-698.

10. He, F.J.; Jenner, K.H.; Farrand, C.E; MacGregor, G.A. World salt awareness week. J. Clin. Hypertens. 2011, 13, S141-S145.

11. He, F.J.; Jenner, K.H.; MacGregor, G.A. WASH-World action on salt and health. Kidney Int. 2010, 78, 745-753.

12. Woodward, E.; Eyles, H.; Mhurchu, C.N. Key opportunities for sodium reduction in New Zealand processed foods. Aust. N. Z. J. Public Health 2012, 36, 84-89.

13. Dotsch-Klerk, M.; Jansen, L. The Choices programme: A simple, front of pack stamp making healthy choices easy. Asia Pac. J. Clin. Nutr. 2008, 17, S383-S386.

14. Conseil de la Transformation Agroalimentaire et des Produits des Consummation (CTAC) Reformulation of Products to Reduce Sodium: Salt Reduction Guide for the Food Industry (in French); CTAC: Quebec, Canada, 2009; pp. 1-76.

15. Fischer, P.W.F.; Vigneault, M.; Huang, R.; Arvaniti, K.; Roach, P. Sodium food sources in the Canadian diet. Appl. Physiol. Nutr. Metab. 2009, 34, 884-892. 
16. Hutchinson, H.; L’Abbé, M.R.; Campbell, N.R.; Tanaka, P. Sodium Working Group: Sodium Reduction Strategy for Canada; Authority of the Minister of Health: Ottawa, ON, Canada, 2010; pp. 1-61.

17. Penz, E.D.; Joffres, M.R.; Campbell, N.R. Reducing dietary sodium and decreases in cardiovascular disease in Canada. Can. J. Cardiol. 2008, 24, S497-S501.

18. World Health Organization Global Strategy on Diet, Physical Activity, and Health, Eighth Plenary Meeting-Committee A, Third Report; World Health Organization: Geneva, Switzerland, 2004; pp. 1-19.

19. Tracking Heart Disease and Stroke in Canada; Public Health Agency of Canada, Heart and Stroke Foundation of Canada: Ottawa, ON, Canada, 2009; pp. 1-115.

20. Sodium Kills 30 Canadians Every Day; Canadian Stroke Network: Ottawa, ON, Canada, 2007; Volume 7, pp. 1-16.

21. Van Vliet, B.; Campbell, N.R.C. Efforts to reduce sodium intake in Canada: Why, what, and when? Can. J. Cardiol. 2011, 27, S437-S445.

22. Joffres, M.R.; Campbell, N.R.; Manns, B.; Tu, K. Estimate of the benefits of a population-based reduction in dietary sodium additives on hypertension and its related health care costs in Canada. Can. J. Cardiol. 2007, 23, 437-443.

23. Reducing the Sodium Intake of Canadians: A Provincial and Territorial Report on Progress and Recommendations for Future Action; Conference of Health Ministers: Ottawa, ON, Canada; pp. 1-40.

24. Improving the Food Environment through Nutrition Standards: A Guide for Government Procurement; National Center for Chronic Disease Prevention and Health Promotion, Centre for Disease Control: Atlanta, GA, USA, 2011; pp. 1-24.

25. Story, M.; Kaphingst, K.M.; Robinson-O’Brien, R.; Glanz, K. Creating healthy food and eating environments: Policy and environmental approaches. Annu. Rev. Public Health 2008, 29, 253-272.

26. L'Abbé, M.; Sunohara, D.; Wan, J. Environmental Scan of Public Food proCurement Policies Related to Sodium; Public Health Agency of Canada: Ottawa, ON, Canada, 2011; pp. 1-93.

27. Under Pressure: Strategies for Sodium Reduction in Institutionalized Environments. Available online: http://www.cdc.gov/salt/pdfs/Institutional_Sodium_Reduction_Guide.pdf (accessed on 27 May 2012).

28. School Food Trust: Eat Better Do Better. Research Report: Primary School Food Survey; England Department of Education: London, UK, 2009, pp. 1-11.

29. UK Target Nutrient Specifications (TNS) For Manufactured Products Used In School Meals, 2005. Available online: http://www.food.gov.uk/multimedia/pdfs/tnssummary.pdf (accessed on 4 June 2012).

30. Food and Catering Services Specifications. Available online: http://sd.defra.gov.uk/advice/public/ buying/products/food/ (accessed on 7 June 2012).

31. School Food Trust: Eat Better Do Better. Research Report: Secondary School Food Survey; England Department of Education: London, UK, 2011; pp. 1-27.

32. Modeling Compositional Changes in School Meals-Further Analysis of the 2004 Survey: School Meals in Secondary Schools in England. Available online: http://www.food.gov.uk/ multimedia/pdfs/modellingchanges.pdf (accessed on 21 February 2014). 
33. Joshi, A.; Kalb, M.; Beery, M. Going Local: Paths to Success for Farm to School Programs. Available online: http://departments.oxy.edu/uepi/cfj/publications/goinglocal.pdf (accessed on 17 May 2012).

34. Schools Food Sales and Policies Provincial Report II. Available online: http://www.bced.gov.bc.ca/ health/sales_policy_feb08.pdf (accessed on 15 July 2012).

35. Understanding Healthy Procurement: Using Government's Purchasing Power to Increase Access to Healthy Food; National Policy and Legal Analysis Network to Prevent Childhood Obesity: Oakland, CA, USA, 2011; pp. 1-18.

36. Gase, L.N.; Kuo, T.; Dunet, D.; Schmidt, S.M.; Simon, P.A.; Fielding, J.E. Estimating the potential health impact and costs of implementing a local policy for food procurement to reduce the consumption of sodium in the county of Los Angeles. Amer. J. Pub. Health 2011, 101, S1501-S1507.

37. Samuels, S.E.; Bullock, S.L.; Woodward-Lopez, G.; Clark, S.E.; Kao, J.; Craypo, L.; Barry, J.; Crawford, P.B. To what extent have high schools in California been able to implement state-mandated nutrition standards? J. Adolescent Health 2009, 45, S38-S44.

38. Simons-Morton, B.G.; Parcel, G.S.; Baranowski, T.; Forthofer, R.; O’Hara, N.M. Promoting physical activity and a healthful diet among children: Results of a school-based intervention study. Amer. J. Public Health 1991, 81, S986-S991.

39. Ellison, R.C.; Capper, A.L.; Goldberg, R.J.; Witschi, J.C.; Stare, F.J. The environmental component: Changing school food service to promote cardiovascular health. Health Educ. Quart. 1989, 16, S285-S297.

40. Jeffery, R.W.; French, S.A.; Raether, C.; Baxter, J.E. An environmental intervention to increase fruit and salad purchases in a cafeteria. Prev. Med. 1994, 23, S788-S792.

41. French, S.A.; Jeffrey, R.W.; Story, M.; Breitlow, K.K.; Baxter, J.S.; Hannan, P.; Snyder, M.P. Pricing and promotion effects on low fat vending snack purchases: The CHIPS Study. Amer. J. Public Health 2001, 91, 112-117.

42. Saksvig, B.I.; Gittelsohn, J.; Harris, S.B.; Hanley, A.J.G.; Valente, T.W.; Zinman, B. A pilot school-based healthy eating and physical activity intervention improves diet, food knowledge, and self-efficacy for native Canadian children. J. Nutr. 2005, 135, S2392-S2398.

43. Auld, G.W.; Romaniello, C.; Heimendinger, J.; Hambidge, C.; Hambidge, M. Outcomes from a school-based nutrition education program using resource teachers and cross-disciplinary models. J. Nutr. Educ. 1998, 30, S268-S280.

44. French, S.A.; Story, M.; Fulkerson, J.A.; Hannan, P. An environmental intervention to promote lower-fat food choices in secondary schools: outcomes of the TACOS Study. Amer. J. Public Health 2004, 94, S1507-S1512.

45. Perry, C.L.; Bishop, D.B.; Taylor, G.; Murray, D.M.; Mays, R.W.; Dudovitz, B.S.; Smyth, M.; Story, M. Changing fruit and vegetable consumption among children: The 5-a-day power plus program in St. Paul, Minnesota. Amer. J. Public Health 1998, 88, S603-S609.

46. Perry, C.L.; Bishop, D.B.; Taylor, G.L.; Davis, M.; Story, M.; Gray, C.; Bishop, S.C.; May, R.A.W.; Lytle, L.A.; Harnack, L. A randomized school trial of environmental strategies to encourage fruit and vegetable consumption among children. Health Educ. Behav. 2004, 31, S65-S76. 
47. Lytle, L.A.; Kubik, M.Y.; Perry, C.; Story, M.; Birnbaum, A.S.; Murray, D.M. Influencing healthful food choices in school and home environments: Results from the TEENS study. Prev. Med. 2006, 43, 8-13.

48. Reynolds, K.D.; Franklin, F.A.; Binkley, D.; Raczynski, J.M.; Harrington, K.F.; Kirk, K.A.; Person, S. Increasing the fruit and vegetable consumption of fourth-graders: Results from the high 5 project. Prev. Med. 2000, 30, S309-S319.

49. Osganian, S.K.; Ebzery, M.K.; Montgomery, D.H.; Nicklas, T.A.; Evans; M.A.; Mitchell, P.D.; Lytle, L.A.; Snyder, M.P.; Stone, E.J.; Zive, M.M.; et al. Changes in the nutrient content of school lunches: Results from the CATCH eat smart food service intervention. Prev. Med. 1996, 25, S400-S412.

50. Bartholomew, J.B.; Jowers, E.M. Increasing frequency of lower-fat entrees offered at school lunch: An environmental change strategy to increase healthful selections. J. Amer. Diet. Assn. 2006, 106, S248-S252.

51. Belansky, E.S.; Cutforth, N.; Delong, E.; Litt, J.; Gilbert, L.; Scarbro, S.; Beatty, B.; Romaniello, C.; Brink, L.; Marshall, J.A. Early effects of the federally mandated local wellness policy on school nutrition environments appear modest in colorado's rural, low-income elementary schools. J. Amer. Diet. Assn. 2010, 110, 1712-1717.

52. Anderson, A.S.; Porteous, L.E.G.; Foster, E.; Higgins, C.; Stead, M.; Hetherington, M.; Ha, M-A.; Adamson, A.J. The impact of a school-based nutrition education intervention on dietary intake and cognitive and attitudinal variables relating to fruits and vegetables. Public Health Nutr. 2005, 8, S650-S656.

53. Recommended Nutrition Standards for Procurement of Foods and Beverages Offered in the Workplace; American Heart Association: Dallas, TX, USA, 2010; pp. 1-4.

54. Pomerleau, J.; Lock, K.; Knai, C.; McKee, M. Interventions designed to increase adult fruit and vegetable intake can be effective: A systematic review of the literature. J. Nutr. 2005, 135, 2486-2495.

55. Lassen, A.; Thorsen, A.V.; Trolle, E.; Elsig, M.; Oveson, L. Successful strategies to increase the consumption of fruits and vegetables: Results from the Danish "6 a day" Work-site Canteen Model Study. Public Health Nutr. 2004, 7, S263-S270.

56. Beresford, S.A.; Thompson, B.; Feng, Z.; Christianson, A.; McLerran, D.; Patrick, D.L. Seattle 5-a-day worksite program to increase fruit and vegetable consumption. Prev. Med. 2001, 32, S230-S238.

57. Sorensen, G.; Stoddard, A.; Peterson, K.; Stoddard, A.; Stein, E.; Phillips, J.; Baker, F.; Combe, C.; Hebert, J.; Palombo, R. Increasing fruit and vegetable consumption through worksites and families in the Treatwell 5-a-day study. Amer. J. Public Health 1999, 89, S54-S60.

58. Sorensen, G.; Stoddard, A.; Hunt, M.K.; Hebert, J.R.; Ockene, J.K.; Avrunin, J.S.; Himmelstein, J.; Hammond, S.K. The effects of a health promotion-health protection intervention on behavior change: The wellworks study. Amer. J. Public Health 1998, 88, S1685-S1690.

59. Perlmutter, C.A.; Canter, D.D.; Gregoire, M.B. Profitability and acceptability of fat- and sodium-modified hot entrees in a worksite cafeteria. J. Amer. Diet. Assn. 1997, 97, S391-S395.

60. Geaney, F.; Harrington, J.; Perry, I. The impact of a workplace catering initiative on dietary intakes of salt and other nutrients: A pilot study. Pub. Health Nutr. 2011, 14, S1345-1349. 
61. Guidance on Food Served to Older People in Residential Care; Food Standards Agency (FSA): London, UK, 2008; pp. 1-27.

62. Johnson, D.B.; Beaudoin, S.; Smith L.T.; Beresford, S.A.A.; LoGerfo, J.P. Increasing fruit and vegetable intake in homebound elders: The Seattle seniors farmers' market nutrition pilot program. Prev. Chronic Dis. 2004, 1, S1-S9.

63. Wekken, S.V.; Naylor, P.-J. Healthy Food and Beverage Sales in Recreation Facilities and Local Government Buildings. Available online: http://www.stayactiveeathealthy.ca/files/Initiative\% 20Summary\%20and\%20Evaluation\%20Synopsis.pdf (accessed on 15 July 2012).

64. Twiss, J.; Dickinson, J.; Duma, S.; Kleinman, T.; Paulsen, H.; Rilveria, L. Community Gardens: Lessons learned from California healthy cities and communities. Amer. J. Public Health 2003, 93, S1435-S1438.

65. Public Sector Food Procurement Initiative (PSFPI): An Evaluation; Department for Environment, Food, and Rural Affairs: London, UK, 2009; pp. 1-78.

66. Norum, K.R. Some Aspects of Norwegian Nutrition and Food Policy. In Diet, Nutrition and chronic disease: Lessons from Contrasting Worlds, Shelty, P., McPherson, K., Eds; Wiley and Sons, Ltd.: Chichester, UK, 1997; pp. 195-206.

67. Sharma, S.; Gittelsohn, J.; Rosol, R.; Beck, L. Addressing the public health burden caused by the nutrition transition through the Healthy Foods North nutrition and lifestyle intervention programme. J. Hum. Nutr. Diet. 2010, 23, S120-S127.

68. Glacken, J.B.; Hill, F. The Food Mail Pilot Projects: Achievements and Challenges; Minister of Indian Affairs and Northern Development and Federal Interlocutor for Métis and Non-status Indians: Ottawa, ON, Canada, 2009; pp. 1-52.

69. Retail Based Nutrition Program; Food Security and Nutrition Unit, Health Canada: Ottawa, ON, Canada, 2009.

70. Health and Sustainability Guidelines for Federal Concessions and Vending Operations. Available online: http://www.gsa.gov/portal/content/104429 (accessed on 15 July 2012).

71. Ligaya, A. Food Fight: High School Students Lobby to Bring Back Pizza, Coffee and Chocolate. Available online: http://news.nationalpost.com/2012/05/07/food-fight-high-school-students-lobby -to-bring-back-pizza-coffee-and-chocolate/ (accessed on 14 July 2012).

(C) 2014 by the authors; licensee MDPI, Basel, Switzerland. This article is an open access article distributed under the terms and conditions of the Creative Commons Attribution license (http://creativecommons.org/licenses/by/3.0/). 